\title{
Camestáo
}

\section{Itinerarios, temas y tramas del coleccionismo arqueológico en el Occidente de México: apuntes para un estado de la cuestión ${ }^{1}$}

\author{
Adrián Acosta Castro \\ Doctorante; Centro INAH Jalisco, Gualajara, México; El Colegio de Michoacán, Zamora, México; \\ acostacastroadrian@gmail.com
}

\begin{abstract}
Resumén: En este artículo trabajaré en torno a tres ejes. En primer lugar, rastreo los principales estudios sobre coleccionismo, expolio y apropiación social del patrimonio arqueológico en el Occidente de México. Posteriormente, reviso algunos planteamientos y cruces teóricos entre la antropología del valor y los estudios de cultura material. Finalmente, presento un par viñetas etnográficas que servirán como anclaje y líneas que orientarán un estudio más amplio sobre dinámicas, actores y prácticas de coleccionismo arqueológico en el Occidente del país.
\end{abstract}

Palabras Clave: Coleccionismo arqueológico. Patrimonio cultural. Materialidad. Usos del pasado. Saqueo.

\section{Introdución}

El Occidente de México, es una región que comparte rasgos geográficos, históricos, culturales y sociales profundos. Comprende los actuales estados de Jalisco, Colima, Michoacán y Nayarit. Ha sido caracterizada desde mediados del siglo XX como una subárea cultural mesoamericana (KIRCHOFF, 1960). Este concepto, aunque con ciertos matices, algunas precisiones y muchas continuidades, sigue vigente en la discusión arqueológica contemporánea. En este contexto, la "Tradición Teuchitlán"² es el nombre acuñado por un grupo de arqueólogos encabezados por Phil Weigand para describir a los grupos culturales que habitaron la región de los Valles de Tequila y áreas circunvecinas del estado de Jalisco, durante el período formativo tardío y clásico temprano de la época prehispánica.

El conjunto de investigaciones arqueológicas desarrolladas en esta región, han aportado de manera importante a romper viejos estigmas de la 
arqueología mesoamericana, al sugerir que estas sociedades, lograron formas complejas de organización social y política, así como dejar de lado la concepción del Occidente de México como una región marginal, pasiva y subordinada a los centros de poder mesoamericanos (WEIGAND; BEEKMAN; ESPARZA LÓPEZ, 2008). Esta agenda de investigación, ha permitido conocer que las sociedades de la Tradición Teuchitlán contaban con arquitectura monumental (Guachimontones, juegos de pelota, tumbas de tiro, etc...) así como estructuras de poder basadas en el linaje, espacios de convivencia social colectiva (banquetes) y sobre todo, una fuerte ritualidad que se expresó de múltiples maneras. No obstante, el campo de investigación específico sobre cultura material, no se ha explorado con la misma consistencia que los estudios arquitectónicos, urbanísticos y las aproximaciones hacia la ritualidad y el poder. Posiblemente esto se debe al abandono académico e institucional, al cual estuvo sometida la región durante décadas. Cabe mencionar que esto ha tenido consecuencias paralelas como el saqueo, tráfico y coleccionismo de piezas arqueológicas.

La cultura material y los objetos elaborados por los grupos de la tradición Teuchitlán, son sumamente vastos y ricos en formas y contenido simbólico (BEEKMAN; WEIGAND, 2000). Este universo de objetos materiales se expresa en iconografías decoradas en ollas, cuencos y platos suntuarios que sugieren demarcaciones de poder; además de ornamentación y objetos elaborados en obsidiana y piedras verdes, hasta figurillas y maquetas que han sido interpretadas como escenas de la vida cotidiana y ritual de estas sociedades. Los objetos que ahora se encuentran exhibidos en los museos locales de la región (Etzatlán, Tala, Teuchitlán, etc.) o aquellos que salieron del país en décadas anteriores y se encuentran en museos de Estados Unidos o Europa, o incluso aquellos objetos que han sido recolectados por campesinos y recolectores locales, pueden brindar pistas importantes para comprender, no solo cómo eran las relaciones sociales de la tradición Teuchitlán, sino (y no menos importante) cómo son entendidos estos objetos en la actualidad. Desde esta perspectiva, las preguntas hacia los objetos arqueológicos no buscarían resolver 
interrogantes del pasado lejano, sino que estarían orientadas a re-evaluar etnográficamente sus significados contemporáneos. ${ }^{3}$

En esta linea, contamos con estudios recientes sobre procesos de socialización, vinculación y puesta en valor del patrimonio arqueológico en algunas comunidades del Occidente de México. Estos trabajos se inscriben en la corriente que se ha denominado Arqueología social (también se le conoce como Arqueología Pública o Interpretativa). En primer lugar, contamos con el trabajo de Jiménez Izarraráz (2015) en la comunidad de Oconahua, en el municipio de Etzatlán, Jalisco. Su planteamiento se orienta a examinar y promover la participación social en torno al proyecto arqueológico en el sito "El Palacio de Ocomo", 4 mediante estrategias, herramientas y perspectivas teóricas y metodológicas provenientes de la escuela de interpretación temática del patrimonio (GÁNDARA VÁZQUEZ, 1998). De manera cercana, contamos con el trabajo reciente de Esparza López y Rodriguez Mota (2016) sobre patrimonio rupestre y petrográfico en los altos de Jalisco. Por otro lado, el trabajo de Zepeda García-Moreno (2000) es pionero en abordar las prácticas vernáculas de coleccionismo y saqueo de piezas arqueológicas en la región, mediante la recopilación de narrativas biográficas, historias de vida y testimonios orales entre los "moneros" ${ }^{5}$ del sur de Nayarit. En esa misma línea, Dansac (2011; 2012) ha documentado cómo en la región jalisciense de los Valles de Tequila, enclavada en el "paisaje agavero", particularmente en Teuchitlán y el sitio arqueológico "Guachimontones" se han registrado prácticas similares a las descritas por Gabriela Zepeda García-Moreno en Nayarit.

\section{Breves apuntes sobre los orígenes del coleccionismo arqueológico en el} Occidente de México

En la literatura especializada sobre coleccionismo arqueológico en México, existe un gran vacío en torno a los antecedentes históricos, así como a las dinámicas sociales, económicas, culturales y políticas que han configurado a dicha práctica en el Occidente del país. A pesar de que existen algunas excepciones importantes (ZEPEDA GARCÍA-MORENO, 2000; DANSAC, 
2011; 2012) generalmente los estudios se han centrado en el coleccionismo como antecedente en la formación del Museo Nacional de México, a principios del siglo XIX (BERNAL, 1979) o bien, en la formación de colecciones en la ciudad de México (ACHIM, 2014) o en el área Maya (SELLEN; LOWE, 2009). No obstante, esto no es fortuito y responde a una agenda específica de la Arqueología mexicana que estuvo dominada durante gran parte del siglo XX, por perspectivas monumentalistas que alimentaron la construcción del EstadoNación y fue en buena medida funcional a la ideología nacionalista que se desarrolló en aquellos años (VÁZQUEZ LEÓN, 2003). ${ }^{6}$

En este contexto, los trabajos del antropólogo noruego Carl Sofus Lumholtz y de la arqueóloga y artista británica Adela Bretón, escritos y publicados entre finales del siglo XIX y principios del XX, son considerados como los primeros acercamientos sistemáticos en torno al estudio de la cultura material prehispánica del Occidente de México. El primero, publicó su libro El México Desconocido, que vio la luz originalmente en 1904. Se trata de un trabajo en donde relata con mucha sensibilidad etnográfica (aunque con una mirada decimonónica fuertemente marcada por imaginarios de clase, colonialidad $)^{7}$ densas observaciones que sintetizan las exploraciones realizadas por el antropólogo entre las tribus de la sierra madre occidental, por los estados de Jalisco y Nayarit, hasta llegar a la zona Tarasca en Michoacán.

En su diario de viaje relata, de manera un tanto dispersa, pero con detalles importantes y acompañamiento visual y gráfico, su paso por mesetas y montañas, los ríos, arroyos y lagos característicos de la geografía regional. Narra algunos episodios que me parecen sumamente interesantes como un entierro descubierto en el jardín de una casa en Tepic (LUMHOLTZ, 1986). Los ocupantes de la tumba estuvieron densamente ataviados y adornados con cascabeles y pectorales. Así mismo narra cómo en algunos casos, los indígenas locales se negaban a venderle figuras antropomorfas (conocidas ya desde este momento como "monos") debido a que pensaban que serían objeto de algún embrujo por parte de Lumholtz. Por otro lado, me llamó la atención cómo hay imaginarios y mitos en torno a los objetos arqueológicos que tienen una densidad histórica profunda. Por ejemplo, el siguiente pasaje descrito por 
Lumholtz (1986, p. 295) sobre la idea de encontrar oro dentro de los objetos, ilustra este planteamiento:

Por desgracia, los descubridores [sic] [de una tumba] ignoraban el valor científico de sus hallazgos que enviaron en burros a la ciudad, donde están distribuidos hoy como curiosidades entre muchas personas, los más grandes fueron rotos porque los compradores esperaban encontrarlos llenos de oro... logré rescatar para la ciencia lo que quedaba de tan importantes antiguedades.

Otro punto a destacar en esta narración tiene que ver con el poco aprecio que se tenía (quizás eso no ha cambiado tanto) por las piezas arqueológicas por parte de los locales. Al continuar su expedición, se dirige de Ixtlán, Nayarit, hacia Guadalajara, para continuar hasta Michoacán. Pasa por la ruta MagdalenaSan Juanito, es decir, la región de los Valles de Jalisco. En este trayecto describe cómo envió a sus peones a buscar y comprar antiguedades en las casas de las comunidades, va recolectando piezas a lo largo de su viaje. Un aspecto importante es que, pese a que no existía prácticamente ningúna investigación sistemática en la región, logra establecer algunas impresiones y relaciones entre las piezas de Ixtlán, con las piezas Tarascas de Michoacán (Fig. 1).

Figura 1 - Ilustración de piezas identificadas como Tarascas

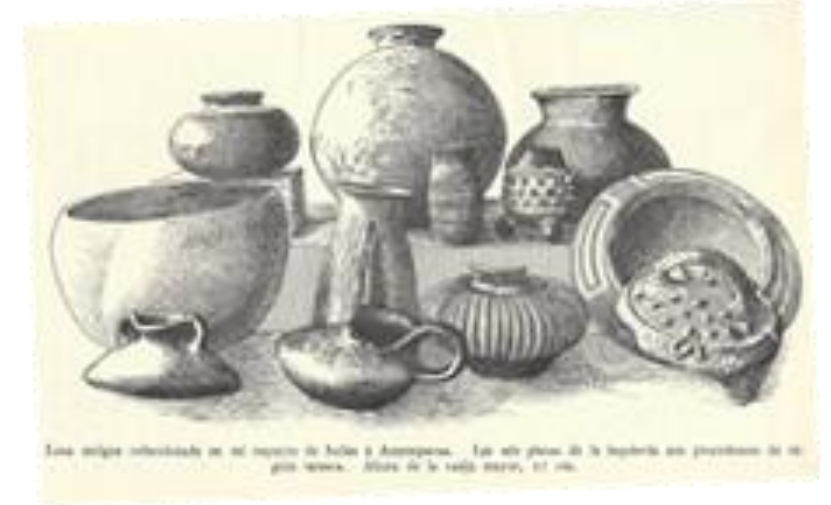

Fuente: Lumholtz (1986, p. 395).

Otro aspecto que me parece sumamente interesante en el trabajo de Lumholtz, tiene que ver con la manera de documentar su exploración, mediante el uso de la cámara fotográfica, dibujos e ilustraciones de lo que va narrando (Figs. 2 y 3), así como de los objetos que encuentra (Fig. 4). Esta práctica tiene una clara influencia de antropólogos contemporáneos como Margaret Mead, 
Gregory Bateson o Franz Boas, quienes incluyeron dispositivos de registro visual (principalmente cámaras fotográficas) con motivos muy diversos: motivar la interacción con indígenas, documentar y registrar mediciones antropométricas, surtir imágenes para los museos occidentales o bien, como material de divulgación (como en el caso de Boas con respecto al museo de historia natural de Nueva York). Malinowski, por ejemplo, utilizó la cámara fotográfica para documentar el folklore, la indumentaria y los artefactos de los grupos indígenas que habitaban en las islas Trobriand. No obstante, para Malinowski el registro fotográfico ocupó siempre un lugar secundario en su metodología de trabajo, sirvió como una especie de "ilustración" o muletilla de la etnografía escrita; mientras que para los primeros impulsores de la antropología visual, como Margaret Mead o su entonces esposo Gregory Bateson, los dispositivos (audio)visuales constituyeron una parte fundamental en su método de recolección y análisis de datos.

Figura 2 - Lumholtz usando una china para protegerse de las inclemencias del tempo

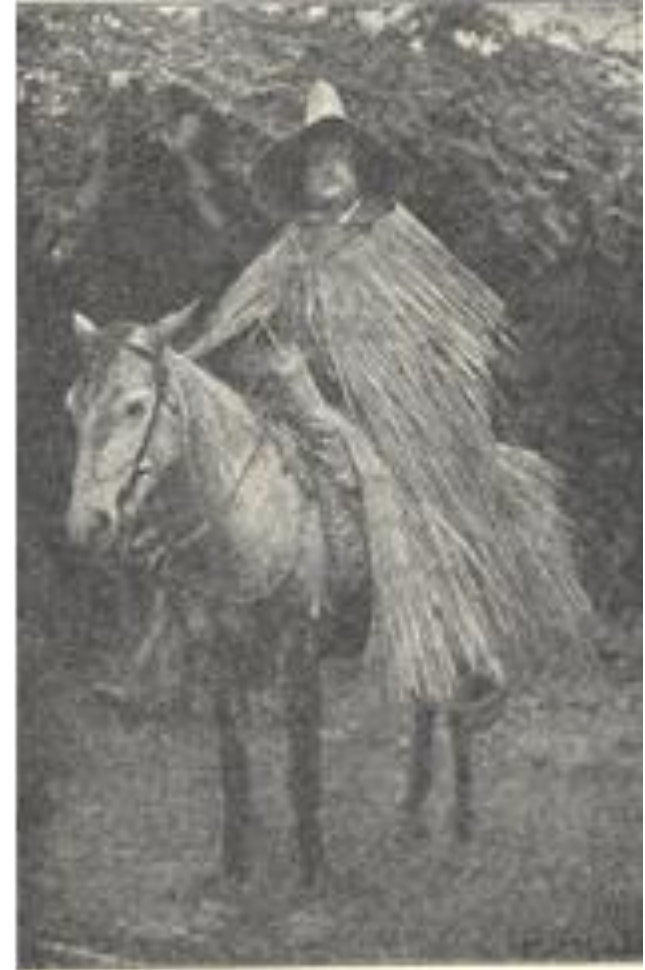

El autor cubicrto coe una china.

Fuente: Lumholtz (1986, p. 324). 


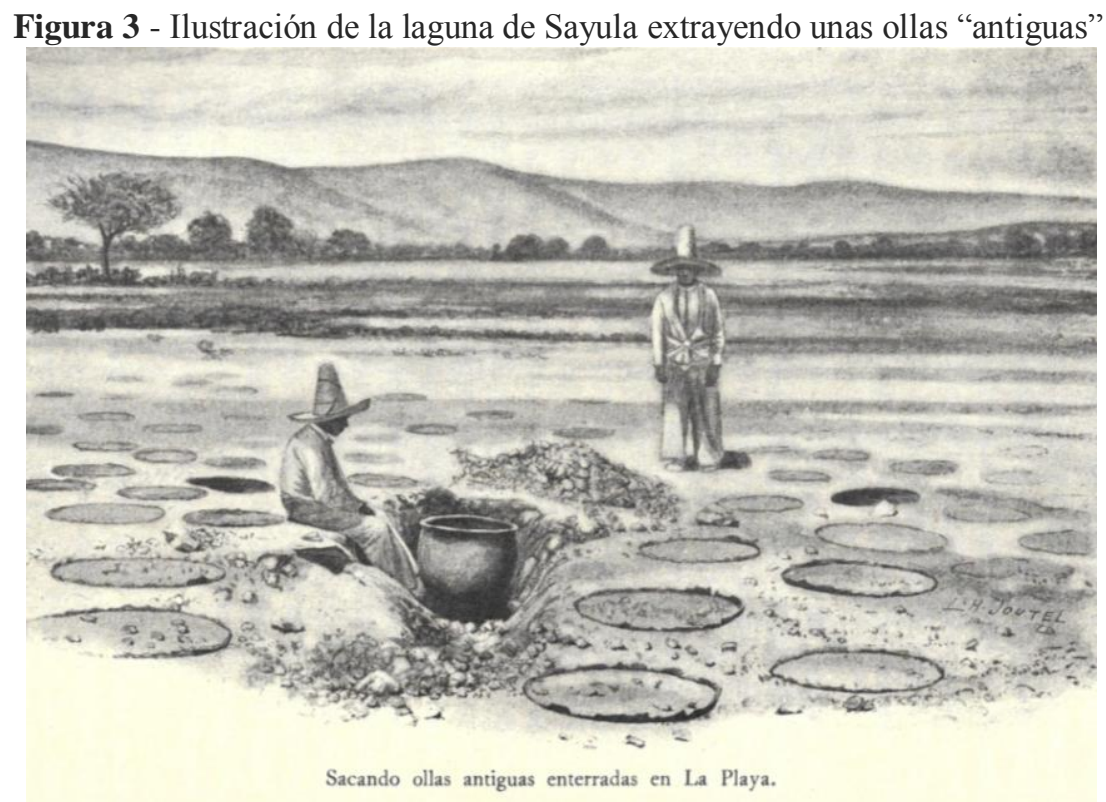

Fuente: Lumholtz (1986, p. 315).

Figura 4 - Piezas estilo "Ixtlan" recolectadas por Lumhotlz en su paso por Nayarit
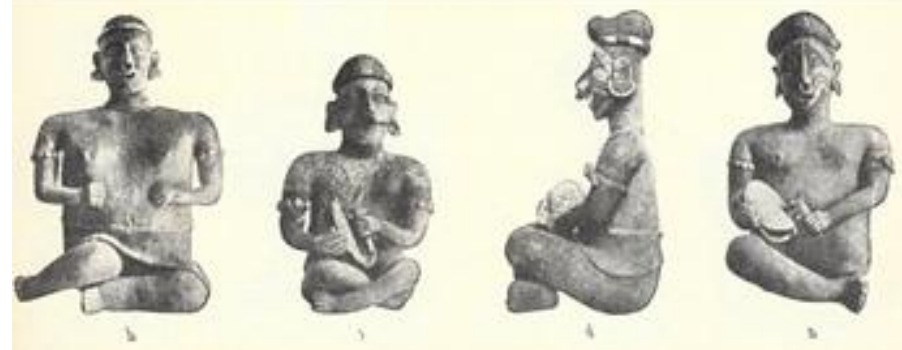

Fuente: Lumholtz (1986, p. 320).

Finalmente, el autor nos da pistas de procesos muy arraigados como el mestizaje sui generis que se dio en la región. Es decir, un mestizaje que se fincó mucho más en la religiosidad y devoción popular que en la identidad étnica, de ahí la importancia que reviste la devoción hacia los santos y las profusas fiestas patronales que continúan vigentes hasta nuestro tiempo. Para decirlo en palabras de Lumholtz (1986, p. 320):

En cuanto a los indios de esos parajes (refiriéndose a Zapotlán el Grande) han perdido enteramente sus antiguas costumbres y apenas se acuerdan de su lengua nativa. A pesar de esa mexicanización, los dioses de sus antepasados siguen rigiendo el espíritu de sus descendientes. 
En suma, considero que el trabajo de Lumholtz es importante por tres motivos principales:

a) en primer lugar, realiza un esfuerzo por vincular a las culturas antiguas (prehispánicas) con los indios "civilizados". Es decir, traza algunas líneas que permitirán realizar análisis etnohistóricos, como los que han sido desarrollados por parte de Phil Weigand y su equipo de trabajo;

b) hace un esfuerzo reflexivo por comparar a las culturas prehispánicas de la región, con las civilizaciones europeas de su momento;

c) resalta la importancia y las bondades del arte y la estética plasmada en la cultura material y específicamente en las figuras de arcilla realizadas en la región.

Por su parte y a pesar de no haber realizado una documentación tan extensa sobre la región (como lo hizo Lumholtz) Adela Breton registró con mucha astucia algunas piezas arqueológicas regionales. Además, realizó el que se considera como primer croquis o boceto del sitio arqueológico "Los Guachimontones", lo cual, en sí mismo representa un aporte muy relevante para la arqueología regional. De acuerdo con Weigand y Williams (1997, p. 218), algunos de los aportes más importantes que Adela Breton realizó a la arqueología temprana en Occidente fueron básicamente tres:

a) asoció las figurillas huecas de cerámica del periodo Formativo y de inicios del Clásico (ca. 300 a.C.- 400 d.C.) en la zona de TeuchitlanEtzatlan, Jalisco, que ella exploró, con la arquitectura de superficie de los mismos períodos;

b) observó la ocurrencia natural y la importancia de la obsidiana en el Occidente;

c) documentó la presencia de la arquitectura circular que ahora sabemos sirvió como el rasgo distintivo de la Tradicion Teuchitlan durante los períodos Formativo y Clásico.

En conjunto, considero que los trabajos realizados por ambos exploradores constituyen documentos importantes para conocer la génesis histórica del coleccionismo arqueológico en el Occidente de México. En este sentido, me parece que reflejan precisamente que el conocimiento que hemos 
acumulado en torno a las culturas prehispánicas de la región y a diferencia de otras áreas culturales de Mesoamérica, ha sido fragmentario y disperso, metáfora que se materializa en cómo se han dispersado los objetos de arqueológicos de esta región en los museos europeos, norteamericanos e incluso en los propios museos locales, así como en colecciones privadas que se encuentran regadas, tanto en las capitales de los estados, como en los mismos pueblos de la región. No obstante, hay que entender esta particularidad del coleccionismo en el Occidente de México, no como algo exterior o como una excepción, sino como parte integral y fundante de cómo se ha conocido y practicado la arqueología regional.

\section{Tala y Etzatlán: la colección, lo gigantesco y la réplica como apropiación y circulación material de narrativas patrimoniales}

Desde mediados del siglo XX, el occidente de México en general, pero de manera notable la región de los Valles de Jalisco, se ha configurado como escenario donde se desarrollan prácticas de expolio, saqueo, coleccionismo y recolección de piezas arqueológicas en distintos niveles. Esto ha significado la creación de imaginarios vernáculos y formas locales de valor que se relacionan más con el territorio, las necesidades inmediatas de la población, los vínculos con el entorno natural y con la apropiación social, cultural y política de los sitios y objetos arqueológicos, que con relatos de identidad nacional o con discursos patrimoniales.

En este sentido, el trabajo de Zepeda García-Moreno (2000) es, sin duda, uno de los trabajos pioneros en abordar desde una perspectiva etnográfica, las dinámicas sociales y culturales del saqueo y coleccionismo de piezas arqueológicas en el occidente de México. Considero que es un aporte muy importante en varios sentidos. En primer lugar, porque sitúa una mirada compleja sobre el problema aludido, desde la perspectiva de los sujetos y actores sociales (algo no muy común en la disciplina arqueológica) y logra cruzar estas miradas situadas de los sujetos, con los aspectos estructurales y dimensiones macro del campo patrimonial mexicano, sus discursos y aparatos normativos. 
$\mathrm{Su}$ objeto de estudio son las formas y prácticas de conocimiento vernáculo que generaron los "moneros" del sur de Nayarit (generalmente campesinos que por diversos motivos vieron en esta práctica una actividad redituable, no solo en el sentido económico, sino a partir de dimensiones simbólicas, culturales y de modo de vida) que, desde entre la década de 1940, hasta principios de los 70's, saquearon las tumbas de tiro en Ixtlán del Río, Nayarit y áreas circundantes. Mediante la recopilación y análisis de testimonios orales sobre hallazgos, saqueos, narraciones, relatos sobre tesoros, ánimas y encantamientos, Zepeda García-Moreno contrasta estos imaginarios locales, con el lenguaje técnico de la arqueología. En este sentido, comenta la autora, lo que ella (arqueóloga profesional) concebía como patrones de asentamiento, posición estratégica, sitios ceremoniales, unidades habitacionales, etc... para los miembros de la comunidad eran lugares de más antes, monos, pozas, lozas, cimborros, ceborucos, lugares buenos pa'1 sutento, gobernación de los indios, etc... Esto evidencia la multiplicidad de valores, sentidos y significados constridos en torno a los sitios y objetos arqueológicos, que sintetizan los distintos tipos de conocimiento (vernáculo/científico) que se disputan en el campo patrimonial. ${ }^{8}$

Es importante señalar que Zepeda García-Moreno (2000, p. 20) - y comparto su posición - aborda al saqueo como "[...] un hecho social inmerso en un sistema de relaciones (políticas, sociales y culturales) situado en un contexto histórico determinado [...]" (más allá de descalificarlo inmediatamente como un delito. En este sentido, es congruente con su planteamiento al efatizar la perspectiva del actor social y rescatar sus aportes, mediante técnicas etnográficas e instrumentos cualitativos (historias de vida, historia oral, vida cotidiana, etc.). ${ }^{9}$

Buscando aportar en esta dirección, quisiera llamar la atención sobre dos escenarios etnográficos que funcionarán para movilizar discusiones sobre autenticidad, legitimidad, producción de políticas de memoria y usos sociales del patrimonio. El primer escenario es el Museo Arqueológico Tlallan (integrado a la Casa de la Cultura de Tala), así como su relación con el resto de la colección que se encuentra en la casa de José Guadalupe Romero (el artista y 
recolector de las piezas arqueológicas que ahora forman parte de la colección de dicho museo). El segundo, se trata del Museo "Oaxicar", igualmente albergado en la Casa de la Cultura de Etzatlán, así como la relación que tiene con algunas réplicas en gran formato que se encuentran en el espacio público, justo en la entrada del municipio. Estos espacios comparten un mismo paisaje cultural situado en el centro-oeste de Jalisco y a unos cuantos kilómetros del Área Metropolitana de Guadalajara.

Cabe mencionar que esta región ha experimentado procesos recientes de patrimonialización, intervención, puesta en valor e investigación de los sitios arqueológicos localizados en su territorio que no serán tratados aquí. Un par de ejemplos son la Declaratoria del Paisaje Agavero y las Antiguas Instalaciones del Tequila (2006) por parte de la Organización de las Naciones Unidas para la Educación, la Ciencia y la Cultura (UNESCO) (GÓMEZ ARRIOLA, 2009) además de la creación o reestructuración de los Museos Arqueológicos antes mencionados (entre 2006 y 2012), así como el proyecto de investigación arqueológica denominado "El Palacio de Ocomo" en Oconahua, localidad que forma parte del municipio de Etzatlán (JIMÉNEZ IZARRARÁZ, 2015). Estos procesos y proyectos han tenido efectos y consecuencias específicas en el sentido de establecer narrativas sobre el pasado prehispánico vinculadas con agendas que buscan dinamizar el turismo, la economía o el sentido de pertenencia y apropiación del patrimonio, pero en este caso servirán como contexto de lo que me interesa problematizar: las prácticas de re-colección y los montajes públicos del pasado.

En términos metodológicos, tomaré como base una entrevista semiestructurada con un actor social clave que, durante más de tres décadas de su vida, formó una colección de piezas arqueológicas que actualmente se exhiben (parcialmente) en el museo arqueológico "Tlallan", en Tala. Busco reflexionar sobre las formas y criterios de valor que son relevantes para el coleccionista, además de trabajar en torno a su agenda y estrategia política de "rescate del patrimonio" frente al despojo y voracidad del saqueo arqueológico que experimentó su comunidad (y que él mismo presenció) durante las últimas décadas del siglo pasado. 
En un segundo momento, reflexionaré en torno a las formas visuales y materiales de circulación, replicación, transformación y consumo de objetosimágenes arqueológicos en las comunidades elegidas, asumiendo que "[...] los procesos de producción, replicación y dispersión que casi invariablemente se adhieren a, o incluso generan, renombre en bienes culturales, no son epifenoménicos, sino integralmente co-constitutivos de valor y potencia." (ROZENTAL; COLLINS; RAMSEY, 2016, p. 9).

Enmarco el análisis en algunas perspectivas recientes sobre la relación entre objetos patrimoniales y nuevas formas de valor que se crean una vez que se transforman en réplica (ROZENTAL, 2014). En este sentido, se ha demostrado que:

[...] las economías auxiliares pueden literalmente remodelar los patrimonios como recuerdos, modelos, réplicas o reconstrucciones. En lugar de presentar estas copias como los efectos secundarios banales de la mercantilización y el turismo, como kitsch o falsificaciones que son infieles a sus referentes, se aborda a los objetos y las relaciones sociales, entendiendo la iteración como central a la constitución y negociación del patrimonio, un discurso o género típicamente presentado como descansando sobre los reclamos de singularidad, autenticidad, continuidad y legado (ROZENTAL; COLLINS; RAMSEY, 2016, p. 9).

Por otro lado, tomo en cuenta el análisis de Özyürek (2004) en torno a la omnipresencia del Estado Turco en la vida cotidiana de la sociedad a través de la cultura material. Esto es, mediante la circulación y consumo del símbolo de Ataturk, el "padre de la patria" en objetos-imágenes que van desde pins, posters y cuadros en pequeño formato que habitan en el espacio doméstico de las personas; hasta esculturas, bustos y mantas en gran formato que penden en montañas y edificios públicos. Esto nos remite al problema de la inserción de imágenes en circuitos sociales de producción, circulación/distribución y consumo. $^{10}$

Finalmente, tomo en cuenta algunos elementos de la discusión sobre los "patrimonios enredados" y los usos del pasado en perspectiva poscolonial (KALTMEIER; RUFER, 2017) y la propuesta de Rufer (2016) sobre el patrimonio como un "regalo envenenado". En trazos amplios, estas aproximaciones enfatizan la naturaleza colonial de los discursos y narrativas 
patrimoniales que, desde la construcción de los estados nacionales Latinoamericanos, se han mimetizado y se han reproducido en distintos espacios sociales, culturales y políticos; pero se olvida que, y esto es lo que considero más relevante: "[...] son sociedades que fueron gestadas, administradas y políticamente reguladas bajo regímenes coloniales modernos: sociedades atravesadas por la 'colonialidad del poder'" (KALTMEIER; RUFER, 2017, p. 2).

No obstante, en las siguientes líneas avanzaré en torno a los dos problemas etnográficos antes mencionados: a) las dinámicas de re-colección y rescate de piezas arqueológicas desarrolladas por José Guadalupe Romero, artista plástico y actual encargado del Museo Arqueológico Tlallan, en Tala; b) la configuración de montajes y despliegues públicos de réplicas y piezas arqueológicas en Etzatlán.

\section{Re-colección, rescate y memorias de la perdida}

Fue una fiebre de saqueadores, principalmente en los 70's y los 80's. En los 90’s comienza a declinar eso de encontrar más piezas o más vestigios porque se los acabaron, literalmente. Antes estaba donde quiera salpicado, donde quiera se podía encontrar algo... como ya fue muy rebuscado, en estos años ya es muy mínimo que se hable de que los saqueadores continúan con su buena racha, tristemente se ha perdido muchísimo, casi todo, por el saqueo... El museo de Tala, es un pequeño rescate que tenemos, de tanto que se ha ido. (GUADALUPE ROMERO, 2017).

A pesar de que resulta prácticamente imposible tener cifras o indicadores precisos, que permitan conocer las dinámicas de expolio y saqueo de piezas arqueológicas en términos estadísticos (debido, en gran parte, a la naturaleza "ilegal" de este tipo de prácticas); en el occidente de México ha sido un fenómeno importante en la historia reciente. ${ }^{11}$ No obstante, más allá de ofrecer datos legales, institucionales o normativos, ${ }^{12}$ me parece más productivo reflexionar en términos cualitativos, sobre cómo fue integrada esta colección en particular. Cabe mencionar que, entiendo a la colección como un dispositivo que materializa la circulación social de diversas narrativas en torno al pasado prehispánico local; y entiendo a este tipo específico de coleccionismo (que se 
manifiesta bajo códigos de recolección y rescate), como la praxis social que permite su funcionamiento. Bajo este enfoque, los objetos integrados en la colección y sus formas de valor, no responden necesariamente (o al menos, no únicamente) a criterios de autenticidad y patrimonio. No obstante, en la siguiente sección presento una reflexión a partir del relato de vida de José Guadalupe Romero.

\section{José Guadalupe Romero: artista y recolector de arte prehispánico}

José es un artista de Tala que desde finales de la década de 1960, se dedicó a formar una colección de "arte prehispánico" (de acuerdo con su propia definición) integrada principalmente con piezas y objetos arqueológicos provenientes de los alrededores del pueblo. A finales de la década de 1990 él, junto con otras personas interesadas, gestionaron la creación de un museo local de arqueología. En sus inicios, el museo fue pensado, no como un museo comunitario, sino como um museo privado, pero esto no fue posible debido a que no contaron con los recursos económicos necesarios; en su lugar, consiguieron el apoyo del gobierno municipal y de Jalisco. Por lo tanto, el museo es administrado por el gobierno municipal, fue inaugurado en $1999 \mathrm{y}$ posteriormente, en el año 2006, el museo fue objeto de una reestructuración y la elaboración de nuevo guión que permanece hasta la fecha. ${ }^{13}$

Al preguntar sobre sus inicios en esta práctica, José me cuenta: "El inicio fue al azar, simplemente caminando en el bosque o en los campos de cultivo que rodean el municipio, o que están dentro del município.” (GUADALUPE ROMERO, 2017). Hay que tomar en cuenta que en estos años (60' s y 70' s), incluso hasta muy entrado el siglo XX, la arqueología del occidente de México, fue marginal con respecto a la practicada en el centro y sureste del país (VÁZQUEZ LEÓN, 2003). No obstante, algunos de los pocos estudios arqueológicos se realizados en la región, se basaron en colecciones particulares y piezas "descontextualizadas" (FURST, 1965; LONG, 1966). ${ }^{14}$ Sumado a esto, unos años antes las piezas precolombinas características de esta región, adquirieron visibilidad y proyección internacional en los circuitos del 
coleccionismo, debido en gran medida a la exposición de piezas del antiguo occidente de México, montada en el Palacio de Bellas Artes de la ciudad de México en 1946 y que se integró fundamentalmente con piezas de la colección de Diego Rivera, uno de los principales exponentes de la escuela de muralismo mexicano. $^{15}$

No obstante y volviendo al caso que nos ocupa, desde su experiencia de vida y al preguntar su opinión sobre el saqueo en Tala, José comenta que uno de sus principales motivos para comenzar a recolectar piezas arqueológicas (Fig. 5), fue precisamente darse cuenta que existía una red de coleccionistas y personas que encontraban una opción lucrativa en esta práctica:

El saber que hay gente que vive de la compra-venta de estas piezas, del tráfico de piezas arqueológicas, gente que se les conoce con el nombre de saqueadores, pues que van directamente a excarvar, buscar y encontrarlos, sacarlos y venderlos inmediatamente. Por lo general, había en esos tiempos, gente interesada, extranjeros, o gente pudiente que les compraba de manera directa, después cuando hubo más control por parte de autoridades, ya había nada más contactos por medio de teléfonos, de los mentados coyotes, el coyote nada mas se dedicaba a hacer el enlace para llevarle al último comprador... El interés es el dinero, me di cuenta de todo ese movimiento y traté de hacer amistad con el único afán de acrecentar mi colección, pero el afán entre comillas de rescatarlos' porque la verdadera intención fue, retenerlos conmigo para siempre, protegerlos o estar al pendiente. Asi fue como creció más al yo entrar en contacto con los saqueadores, nunca fui a excarvar (sic) por mi cuenta, nunca cometí esa parte porque es delito, mejor los buscaba, trataba de apoyarlos digamos, de transportarlos, darles alimento a esos saqueadores, para yo obtener algo, las migajas porque siempre me daban lo que ellos no querían, ellos buscaban lo mejor, piezas muy grandes, con mucha vista, porque asi es este tráfico, el comprador quiere lo mejor y sus precios siguen siendo altísimos, yo nunca tuve dinero para comprar piezas como las que ellos acostumbraban comerciar, me quedaba con lo chiquito, todo lo que ellos no querían, algunas veces se los pagaba otras veces me los regalaban, porque yo contribuía con algo, así empezó... (GUADALUPE ROMERO, 2017).

De este fragmento me interesa resaltar dos cosas: primero, al reconocer la existencia de esta red de coleccionistas, vendedores y demás intermediarios, decide iniciar una agenda que busca "rescatar" lo que sea posible para proteger las piezas y de esta manera evitar su dispersión hacia otros sitios geográficos. 
Figura 5 - Una parte de la colección de José Guadalupe Romero, dispuesta en una vitrina en su

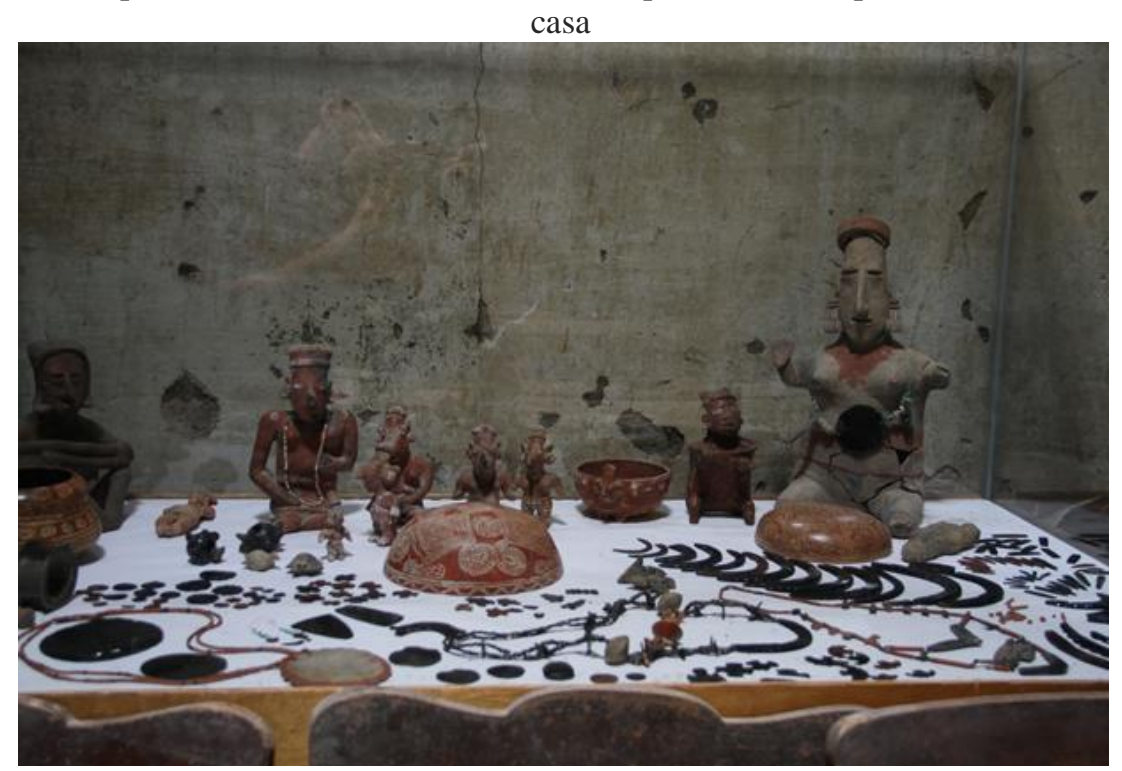

Fuente: Del autor.

Asume, en este sentido, el lugar autoasignado de "custodio" del patrimonio y de esta manera, busca llenar un espacio vacío, eludido por la responsabilidad que tiene el Estado, al ser éste el supuesto garante de la protección del "patrimonio de la nación". ${ }^{16}$ En segundo lugar, me llama la atención su predilección por las piezas pequeñas:

Este museo no tiene piezas tan monumentales, lo importante es que los saqueadores no se dan cuenta que las piezas más pequeñas, tienen mas arte, son mas minusciosas en su elaboración. Hay mas trabajo en las cosas pequeñas que en las grandes, ellos no notaban eso... que bueno que me quedé con las cosas mas pequeñas, porque son un gran imán para la gente que aprecia los museos arqueológicos. (GUADALUPE ROMERO, 2017).

Como ha señalado Walter Benjamin, el coleccionista es una figura dominada por una singular obsesión burguesa (privada) ligada a la pulsión de aferrarse a épocas pasadas a través los objetos:

Coleccionar es una forma de recordar mediante la praxis y de entre las manifestaciones profanas de la cercanía, la más concluyente [...] el verdadero método para hacerse presentes las cosas, es plantarlas en nuestro espacio y nosotros en el suyo (eso hace el coleccionista y también la anécdota). La contemplación de grandes obras pasadas también es una recepción de ellas en nosotros. Además del aspecto contemplativo, los coleccionistas son hombres con instinto táctil, porque la propiedad y el tener se subordinan al tacto, en relativa oposición a lo óptico. (BENJAMIN, 2005, p. 223-225). 
Esto es precisamente lo que busca José. Las piezas arqueológicas funcionan como una suerte de materialización del tiempo. Son "ventanas al pasado", pero no un pasado abstracto que (para él) deba ser explicado en términos científicos, sino un pasado que alimenta su admiración y deseos por "sentir" y conocer más sobre las sociedades que produjeron estos objetos. En sus palabras, José pliega sus intereses al ámbito de la historia:

Me atrae más el pasado que lo que viene, el pasado me parece más rico que el futuro, porque ya está todo aquí. Entonces, darte cuenta que dos mil, o tres mil años atrás, la gente que estuvo aquí viviendo, gente como nosotros, sin mas modernidades, como hoy, hacían muchísimas cosas que hasta la fecha, hay incógnitas de cómo se daban para poder lograr lo que a nosotros nos asombra... me hago del lado de ellos, porque siento mucho la historia, me atrae mucho la historia, no me veo envuelto en esos días, porque no podemos regresar, pero sería un gran gusto poder hacerlo, si se pudiera, eso es lo que me atrae mas, para haber desarrollado esta colección. (GUADALUPE ROMERO, 2017).

En su casa, además de las piezas arqueológicas, existe un cúmulo de objetos que parecen ser sobrevivientes de otras épocas: un ropero y una cama decimonónica nos reciben. Más adelante, entramos en una habitación donde se acumulan y despliegan libros viejos, básculas y relojes antiguos que penden de las paredes, igual que fotografías que registran escenarios y prácticas sociales de inicios y mediados del siglo XX (el cine teresa, algunos desfiles militares, el ingenio azucarero de Tala, etc.) además de juguetes de latón oxidados, vinilos, un radio y un par de bocinas antiguas, candados y planchas de hierro, un rifle de la época de la revolución, un baúl y algunos candiles, entre otros objetos que conviven desordenados en un mismo espacio (Figs. 6 y 7).

González Stephan (2000) sostiene que antes del siglo XIX, el coleccionismo se vinculaba con el ámbito privado y elitista, posteriormente la emergencia de la burguesía lo pliega al ámbito público y estatal. La colección como dispositivo, estuvo ligada a políticas de conocimiento científico, así como a la creación de una voluntad de saber (poder). ${ }^{17}$ No obstante, más que “coleccionismo", en este caso estaríamos hablando de re-colección, una práctica que busca integrar los residuos o los desechos de aquello que no entra en los 
circuitos más amplios del coleccionismo (nacional o internacional), aquello que no es útil al mercado o representativo de "la nación". Lejos de alimentar nociones ideológicas y nacionalistas de identidad, esta práctica tiene que ver más con la necesidad de visibilizar la huella antigua del tiempo a nivel local, pero al mismo tiempo manipular y "usar" este pasado como estrategia de identificación (HALL, 2003). No se trata solamente de "privatizar" objetos que en teoría nos pertenecen a todos los mexicanos, sino de comprender que debajo de estos mecanismos subyacen formas de violencia, colonialidad y autoridad, que nos obligan a extender las nociones tradicionales del patrimonio.

Figura 6 - Un sticker irrumpe en la vitrina como montaje de tiempos distintos que conviven y se mezclan. En la colección lo importante no es el orden, la taxonomía o la clasificación, sino la contemplación, el caos y el gusto

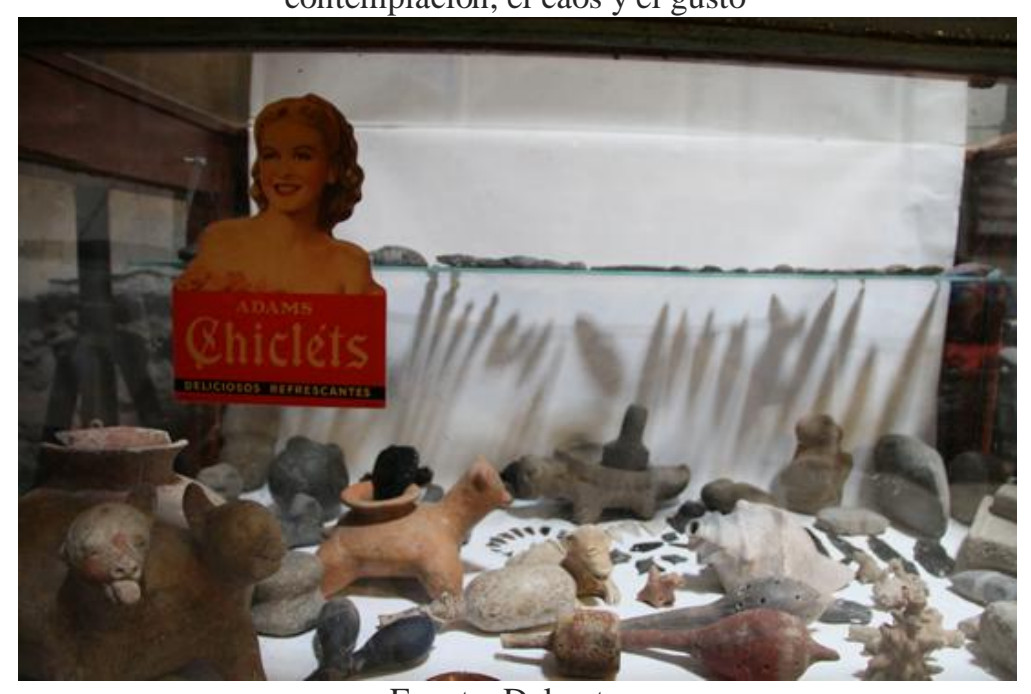

Fuente: Del autor.

Figura 7 - Otros objetos de la colección

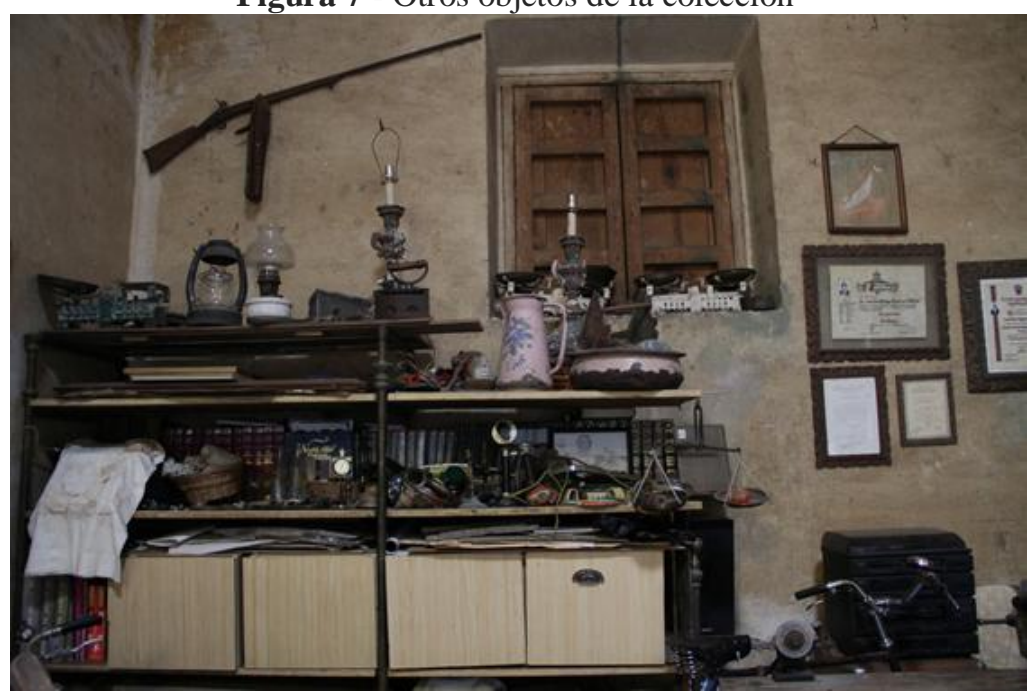

Fuente: Del autor. 
Este planteamiento, también supone no dar por sentada la idea del patrimonio cultural como un espacio plano, neutral o carente de conflictos. Debemos reconocer al patrimonio arqueológico como un dispositivo de memoria (KINGMAN GÁRCES, 2011) que activa mecanismos de reinvención del pasado, mediante la asociación de objetos y sitios arqueológicos con la creación de narrativas sobre el pasado, orientadas a establecer sentidos de pertenencia, identificación cultural y políticas de memoria que funcionan como técnicas de gubernamentalidad (SALGADO GÓMEZ, 2008). Lo anterior implica la construcción de un régimen en donde "[...] todo lo que se describe o identifica como patrimonio, sólo es valioso mientras exista un sentido 'auténtico' del pasado para identificarlo como tal." (ROWLANDS, 2002, p. 108). En otras palabras, para que exista la idea de patrimonio, "[...] debe existir un relato de la nación o de una comunidad, cuyos términos son conocidos y significativos para sus integrantes y para los cuales el 'patrimonio' proporciona una objetivación material del relato." (ROWLANDS, 2002, p. 109).

\section{Montaje y materialidad: réplicas, imágenes y representaciones locales de lo prehispánico}

Al llegar a Etzatlán, nos recibe un montaje arqueológico peculiar: se trata de una réplica en gran formato, que representa a un "Guerrero" o un "Chaman" sentado sobre un montículo que simula ser un Guachimontón (edificio prehispánico circular característico de la zona) detrás del anuncio: Etzatlán Zona Arqueológica (aunque en realidad no se trata de un sitio arqueológico, en el sentido tradicional) que se encuentra incrustado en una pequeña barda rematada por tres macetas (Fig. 8). La escultura se encuentra en posición defensiva, ataviado con una protección en el cuerpo, un casco y un mazo. Este tipo de figuras son características de la tradición tumbas de tiro y la pieza original (Fig. 9) se encuentra en el museo arqueológico "Oaxicar", que se localiza en la casa de la cultura del municipio. A unos cuantos metros, se exhiben dos esculturas más, en un corredor que conecta el paisaje visual que comienza en la antigua 
estación del ferrocarril, ${ }^{18}$ continúa por la vía del tren y fluye hasta la calle principal, justo donde se despliegan las esculturas.

Figura 8 - Montaje y producción material del pasado prehispánico local

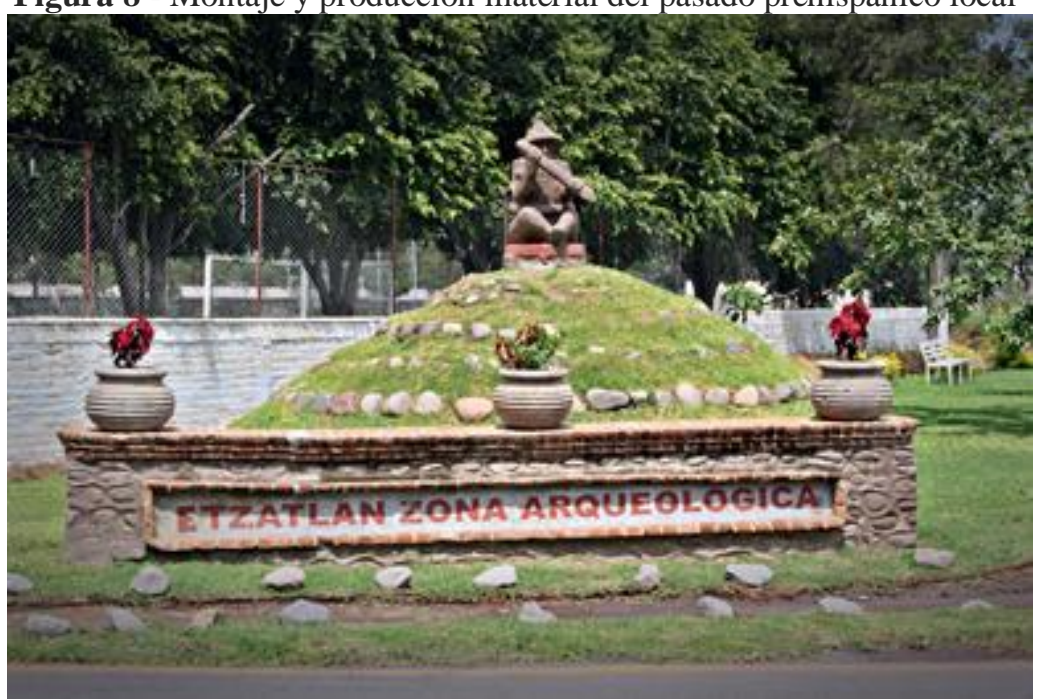

Fuente: Del autor.

Figura 9 - Figura antropomorfa, tradición tumbas de tiro. ¿Guerrero? ¿Chamán?

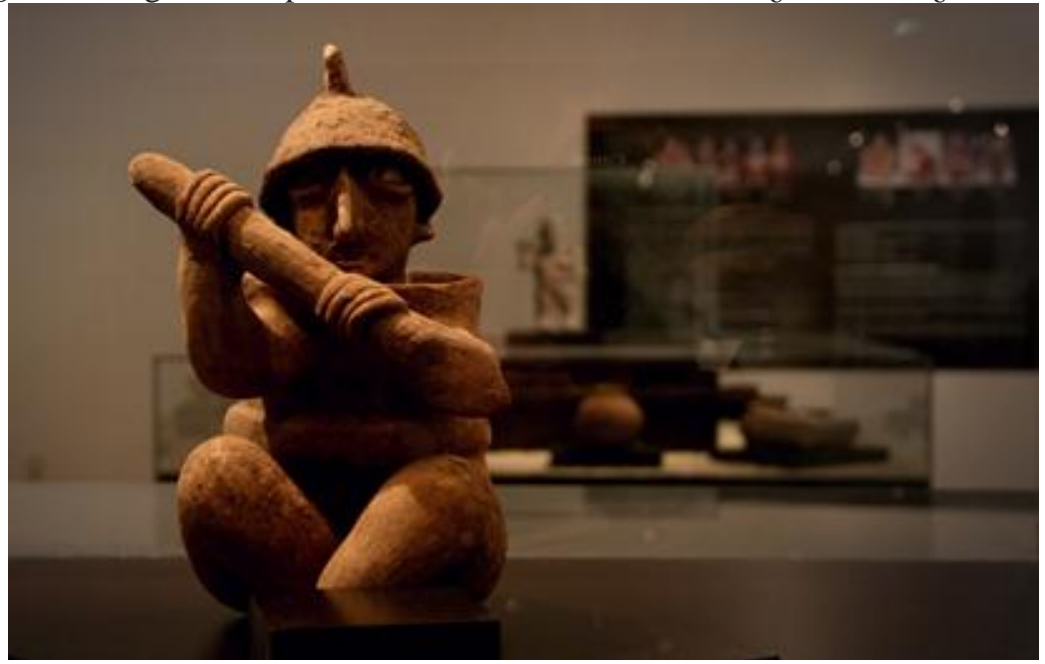

Fuente: Del autor.

No obstante, me interesa resaltar algunos aspectos del escenario antes descrito. En primer lugar, considero que este montaje forma parte de una agenda que buscó resaltar elementos prehispánicos locales para estimular el sentido de pertenencia e identificación cultural, no solo por parte de la población local. La intervención, puesta en escena y despliegue de estas réplicas en el espacio público, reproduce en cierto sentido las estrategias decimonónicas de 
monumentalidad y cultura del espectáculo, pero a nivel local. Como sabemos, a partir del siglo XIX, en los países Latinoamericanos, el "Patrimonio cultural" (así como sus imágenes y referentes) se han convertido en soporte imaginario de la identidad nacional. Las "comunidades imaginadas", se construyeron en torno a una economía de la representación del pasado como espectáculo, que se basó en el monumentalismo, la grandilocuencia, la teatralidad, la cultura del espectáculo y el exhibicionismo. En este sentido, la cultura letrada fue dando paso a cultura visual que obedeció a criterios de consumo y mercado, en el sentido de crear patrimonios nacionales museografiables, coleccionables y con valor exhibitivo, bajo criterios de publicidad, imágen y estandarización (GONZÁLEZ STEPHAN, 2000). ${ }^{19}$ En nuestro caso, a falta de grandes pirámides y sitios arqueológicos, resulta necesario tener "algo" que mostrar, que infunda orgullo de un pasado milenario en la localidad. El valor exhibitivo de estas réplicas, se fundamenta en una economía simbólica, más que en su valor explicativo o en criterios de cientificidad.

Figura 10 - Otra réplica indica el sendero hacia el pueblo

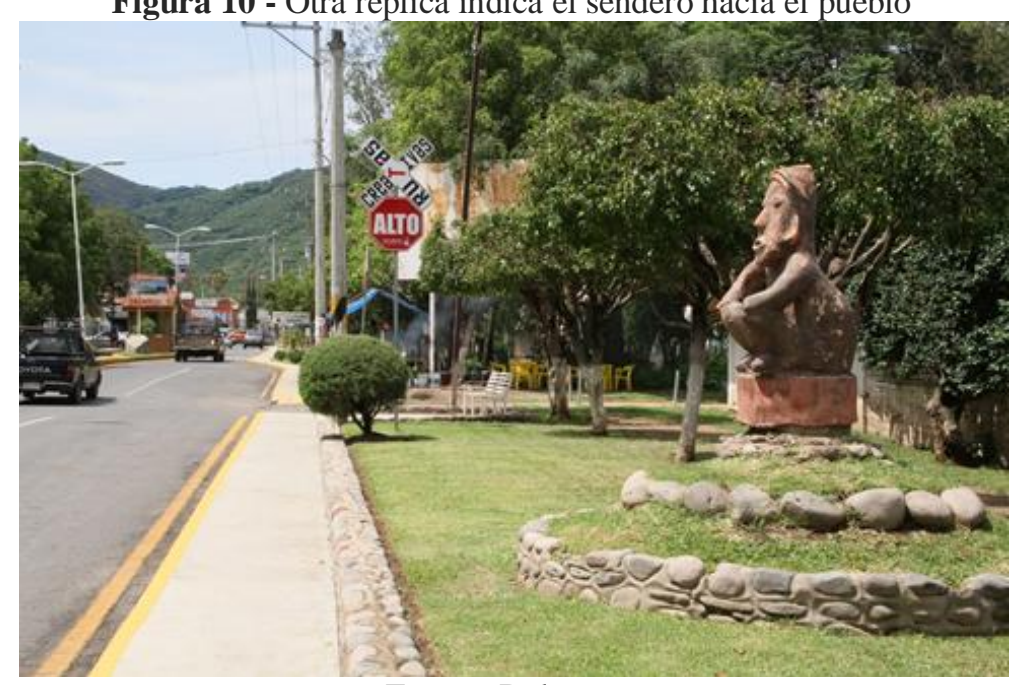

Fuente: Del autor.

Pero para desmenuzar la agenda detrás de estos objetos, vale la pena hacer otro tipo de preguntas: ¿cómo se formó la colección que da origen a estas réplicas? ¿en qué contexto emerge y bajo cuáles narrativas se sustenta el museo arqueológico local? ¿qué nos dice la imágen un "guerrero" prehispánico dispuesto justo en la entrada del pueblo? ¿es en realidad un guerrero ${ }^{20}$ 
La colección que se exhibe en el museo fue formada por un político local que, en el momento de su creación, era presidente municipal. No me interesa extenderme en datos específicos sobre la cantidad o tipo de piezas, o sobre el contexto en el que dicho museo fue creado, porque esa información será tratada en otro trabajo. No obstante, el proyecto de creación del museo también le dio origen al corredor de réplicas antes descritas. A diferencia del caso de Tala, donde la colección fue formada bajo criterios de "rescate" y memoria social, en este caso se trató de una estrategia "cultural" del municipio (por supuesto validada por los distintos órdenes de gobierno) para poner en circulación y volver "visible" el pasado prehispánico local (Fig. 10). Este tipo de montajes del tiempo y producciones materiales de historia no son transparentes, toda vez que se inscriben en las disputas por la memoria pública que compiten por tener un lugar en el teatro de la nación. Recordemos que toda esta región se ha dinamizado en años recientes, debido a los proyectos de intervención patrimonial y cultural (Paisaje agavero, vías verdes, rutas creativas...) bajo lineamientos que responden cada vez más a discursos globales, pero que tienen consecuencias puntuales en el ámbito local. Finalmente, como sugieren Rufer y Kaltmeier:

\footnotetext{
Para entender el carácter enredado y relacional del patrimonio, tenemos que repensar nuestros conceptos... es necesario hablar de la cultura, no solo como un sistema, sino también como un recurso, no solo lidiar con la historiografía, sino también con los 'usos del pasado', no hablar solo de Identidad, sino de procesos de identificación. (KALTMEIER; RUFER, 2017, p. 5).
}

En la medida en la que logremos entender el carácter político, relacional y procesual (no solo folklórico o cultural) del patrimonio, podremos avanzar en comprender su lugar en nuestro tiempo.

\section{Reflexiones finales}

Una buena parte de la literatura especializada en coleccionismo arqueológico en México, se ha centrado en analizar las dinámicas de dicho fenómeno en el siglo XIX y se ha planteado como antecedente y referencia para la formación de 
museos nacionales, regionales o locales. No obstante, existen líneas y perspectivas de investigación que buscan ir más allá de la historia de estas instituciones y en su lugar, analizan las trayectorias de objetos prehispánicos integrados en las colecciones, para establecer cómo los objetos mismos fueron reconfigurando las dinámicas, valores e imaginarios sobre el conocimiento arqueológico a su paso. Lo anterior permite complejizar la lectura del coleccionismo y analizarlo más allá de discursos nacionalistas. No obstante, un segundo cuerpo de estudios especializados, se han centrado en analizar al coleccionismo arqueológico y prácticas asociadas (como el saqueo, compraventa y tráfico ilícito) como parte de una economía ilegal y como un problema que debe enfrentar, tanto la disciplina arqueológica, como el gobierno mexicano. Finalmente, hay un tercer cuerpo de estudios que buscan teorizar sobre los distintos valores construidos en torno a los objetos arqueológicos (principalmente desde el arte y la antropología/arqueología).

El conjunto de estudios y perspectivas teóricas revisados hasta el momento, permiten comprender cómo los distintos valores asociados con las piezas arqueológicas no son inherentes a las mismas, es decir, dependen sus contextos de producción, circulación y destino. En otras palabras, los valores son conferidos $\mathrm{y}$ atribuidos a dichos objetos por personas, discursos o instituciones. En este sentido, el presente ensayo ha sido un intento por articular dos intereses distintos, pero interconectados. En primer lugar, ha sido una revisión teórica en torno a los lenguajes del patrimonio, sistemas de valor y procesos de patrimonialización. Un segundo interés, fue reportar un par de experiencias de trabajo de campo en Tala y Etzatlán, asumiendo que son sitios que condensan diferentes sentidos, miradas y narrativas sobre el patrimonio arqueológico, prácticas de coleccionismo y formas de apropiación de los objetos prehispánicos característicos del Occidente de México.

\section{Referencia}

ACHIM, Miruna. Maleta de doble fondo y colecciones de antigüedades, Ciudad de México, ca. 1830. In: ACHIM, Miruna; PODGORNY, Irina (Ed.). Museos al detalle: colecciones, antigüedades e historia natural, 1790-1870. Rosario: Prohistoria Ediciones, 2014. p. 99-125. 
AZUELA DE LA CUEVA, Alicia. Arte y poder. Ciudad de México: Fondo de Cultura Económica; El Colegio de Michoacán, 2005.

BEEKMAN, Chris; WEIGAND, Phil. La cerámica arqueológica de la tradición Teuchitlán, Jalisco: tipología, análisis petrográfico y cronología. Jalisco: El Colegio de Michoacán; Secretaría de Cultura de Jalisco, 2000.

BENJAMIN, Walter. Libro de los pasajes. Madrid: Editorial Akal, 2005.

BERNAL, Ignácio. Museos y protección de antigüedades. In: BERNAL, Ignácio; PIMENTEL, García (Ed.). Historia de la arqueología en México. Ciudad de México: Miguel Ángel Porrúa, 1979. p. 118-131.

COTTOM, Bolfy. Debates por la cultura: las consultas públicas que precedieron a la promulgación de la Ley Federal sobre Monumentos y Zonas Arqueológicos, Artísticos e Históricos en la Cámara de Diputados. Ciudad de México: Instituto Nacional de Antropología e Historia; Universidad Michoacana de San Nicolas de Hidalgo; Miguel Angel Porrúa, 2016.

DANSAC, Yael. Conceptualizaciones nativas y etnoconocimientos sobre los vestigios prehispánicos en el folclore rural: notas de la exploración del patrimonio etnológico de Teuchitlán (México). Apuntes, Bogotá, v. 25, n. 1, p. 90-101, 2012.

DANSAC, Yael. Entre agaves y moneros: el patrimonio arqueológico del paisaje agavero. Red Patrimonio, La Piedad, p. 1-19, 2011.

ESPARZA LÓPEZ, Rodrigo; RODRIGUEZ MOTA, Francisco Manuel. El santuario rupestre de los altos de Jalisco: participación comunitaria para la conservación del patrimonio cultural y natural en Jesús María, Jalisco. Jalisco: El Colegio de Michoacán; Secretaría de Cultura Jalisco, 2016.

FURST, Peter T. Shaft tombs, shell trumpets and shamanism: a culturehistorical approach to problems in West Mexican archaeology. 1965. Dissertation (Ph.D. in Anthropology). Los Angeles: University of California, 1965.

GÁNDARA VÁZQUEZ, Manuel. La interpretación temática y la conservación del patrimonio cultural. Ciudad de México: ENAH, 1998.

GARRIGAN, Shelley E. Collecting Mexico: museums, monuments, and the creation of national identity. Minneapolis: University of Minnesota Press, 2012.

GONZÁLEZ STEPHAN, Beatriz. Coleccionar y exhibir: la construcción de patrimonios culturales. Hispamérica, College Park, v. 29, n. 86, p. 3-17, 2000. 
GÓMEZ ARRIOLA, Ignacio. El plan de manejo para el Paisaje Agavero y las Antiguas Instalaciones Industriales del Tequila: el patrimonio cultural como detonador del desarrollo regional, antecedentes, compromisos y retos. Apuntes, Bogotá, v. 22, n. 2, p. 124-141, 2009.

GUADALUPE ROMERO, José. José Guadalupe Romero. [nov. 2017].

Entrevistador: Adrián Acosta Castro. Jalisco, 2017.

HALL, Stuart. Introducción: ¿Quién necesita identidad?. In: HALL, Stuart; DU GAY, Paul (Coord.). Cuestiones de identidad cultural. Madrid: Amorrortu Editores, 2003. p. 13-39.

JIMÉNEZ IZARRARÁZ, María Antonieta. La vinculación social en arqueología: planeación de impacto social de un proyecto arqueológico. Zamora: El Colegio de Michoacán. 2015.

KALTMEIER, Olaf; RUFER, Mario (Eds.). Entangled heritages: postcolonial perspectives on the uses of the past in Latin America. Ney York: Routledge, 2017.

KINGMAN GARCÉS, Eduardo. ¿Podemos pensar el patrimonio? políticas de la memoria, el patrimonio y la seguridad. Arxiu d'Etnografia de Catalunya, Tarragona, n. 11, p. 231-253, 2011.

KIRCHOFF, Paul. Mesoamérica, sus límites geográficos, composición étnica y caracteres culturales. Tlatoani, Ciudad de México, n. 3, p. 1-12, 1960.

KIRSHENBLATT-GIMBLETT, Barbara. From ethnology to heritage: the role of the museum. In: CONFÉRENCE DE LA SOCIÉTÉ INTERNATIONALE D'ETHNOLOGIE ET DE FOLKLORE, 8., 2004, Marseilles, Conférence/Lecture. Marseilles: SIEF, 2004. p. 73-80.

LONG, Stanley V. Archaeology of the municipio of Etzatlan, Jalisco. 1966. Dissertation (Ph.D. in Anthropology). Los Angeles: University of California, 1966.

LUMHOLTZ, Carl Sofus. El México desconocido. México: Instituto Nacional Indigenista, 1986.

MEYER, Karl E. EI saqueo del pasado: historia del tráfico internacional ilegal de obras de arte. Ciudad de México: Fondo de Cultura Económica, 1990.

ÖZYÜREK, Esra. Atatürk: privatization of state imagery and ideology in Turkey, American Ethnologist, v. 3, n. 31, p. 374-391, 2003.

PRATT, Mary Louise. Ojos imperiales: literatura de viajes y transculturación. Ciudad de México: Fondo de Cultura Económica, 2010. 
ROWLANDS, Mike. Heritage and cultural property. In: BUCHLI, Victor (Ed.). The material culture reader. Oxford: Berg, 2002.

ROZENTAL, Sandra; COLLINS, John F.; RAMSEY, Jason. Matters of patrimony: anthropological theory and the materiality of replication in contemporary Latin America. The Journal of Latin American and Caribbean Anthropology, New Jersey, v. 21, n. 1, p. 7-18, 2016.

ROZENTAL, Sandra. Stone replicas: the iteration and itinerancy of mexican patrimonio. The Journal of Latin American and Caribbean Anthropology, New Jersey, v. 19, n. 2, p. 331-356, 2014.

RUFER, Mario. El patrimonio envenenado: una reflexión "sin garantías" sobre la palabra de los otros. In: GORBACH, Frida; RUFER, Mario (Org.).

(In)disciplinar la investigación: archivo, trabajo de campo y escritura. Ciudad de México: Siglo XXI editores; Universidad Autónoma Metropolitana, 2016, p. 85-113.

SALGADO GÓMEZ, Mireya. El patrimonio cultural como narrativa totalizadora y técnica de gubernamentalidad. Centro-h, Quito, n. 1, p. 13-25, 2008.

SELLEN, Adam Temple; LOWE, Lynneth. Las antiguas colecciones arqueológicas de Yucatán en el Museo Americano de Historia Natural. Estudios de Cultura Maya, Ciudad de México, v. 33, p. 53-71, 2009.

VÁZQUEZ LEÓN, Luis. El leviatán arqueológico: antropología de una tradición científica en México. Ciudad de México: Centro de Investigaciones y Estudios Superiores en Antropología Social; Miguel Ángel Porrúa, 2003.

WEIGAND, Phil; BEEKMAN, Chris; ESPARZA LÓPEZ, Rodrigo (Ed.) Tradición Teuchitlán. Jalisco: Secretaría de Cultura Jalisco; El Colegio de Michoacán, 2008.

WEIGAND, Phil; WILLIAMS, Eduardo. Adela Bretón y los inicios de la arqueología en el occidente de México. Relaciones, Zamora, v. 18, n. 70, p. 127-256, 1997.

ZEPEDA GARCÍA-MORENO, Gabriela. Guardianes y moneros: patrimonio arqueológico y supervivencia campesina en el sur de Nayarit. 2000. Disertación (Maestría en Antropología Social). Guadalajara: Centro de Investigaciones y Estudios Superiores en Antropología Social - Unidad Occidente, 2000. 


\title{
Itineraries, themes and plots of archaeological collecting in Western Mexico: notes for a state of the art
}

\begin{abstract}
In this article, I will work around three axes. First, it traces the main studies on the collection, looting and social appropriation of archaeological heritage in western Mexico. Later, I review some theoretical approaches and crossings between the anthropology of value and the studies of material culture. Finally, I present a couple of ethnographic vignettes that will serve as anchors and lines that will guide a wider study on dynamics, actors and archaeological collection practices in the west of the country.
\end{abstract}

Keywords: Archaeological collection. Cultural heritage. Materiality. Uses of the past. Looting.

\section{Itinerários, temas e lotes de coleta arqueológica no oeste do México: notas para um estado da arte}

Resumo: Neste artigo, eu trabalharei em torno de três eixos. Primeiro, traça os principais estudos sobre a coleta, saque e apropriação social do patrimônio arqueológico no oeste do México. Mais tarde, reviso algumas abordagens teóricas e cruzamentos entre a antropologia do valor e os estudos de cultura material. Finalmente, apresento um par de vinhetas etnográficas que servirão como âncoras e linhas que guiarão um estudo mais amplo sobre dinâmicas, atores e práticas de coleta arqueológica no oeste do país.

Palavras-chave: Coleta arqueológica. Patrimônio cultural. Materialidade. Usos do passado. Pilhagem.

Recebido: $10 / 11 / 2017$

Aceito: 15/12/2017

1 Una versión anterior del presente artículo fue presentada como ponencia en el simposio Patrimonio cultural, hegemonía y mediaciones sociales en América Latina: agendas de investigación y nuevos escenarios para el siglo XXI del V Congreso de la Asociación Latinoamericana de Antropología, Bogotá, Colombia, junio, 2017. Así mismo, se nutre con ideas desarrolladas en los seminarios y cursos complementarios del Doctorado en Ciencias Sociales (2016-2021) en El Colegio de Michoacán. Particularmente, agradezco los comentarios y sugerencias de Rodrigo Esparza López, Luis Gómez Gastelum, Gabriela Zamorano y Sandra Rozental.

2 El concepto, es producto de una agenda de investigación de largo aliento, impulsada principalmente por investigadores vinculados con El Colegio de Michoacán, mediante el Proyecto Arqueológico Teuchitlán (PAT) y cuyos resultados han sido materializados en múltiples publicaciones, así como en los vínculos establecidos con el gobierno de Jalisco para la creación del Centro Interpretativo Guachimontones, o la implementación de proyectos arqueológicos como el que se está llevando a cabo actualmente en el sitio denominado Palacio de Ocomo, en Etzatlán, Jalisco. 
${ }^{3}$ En la actualidad, los objetos arqueológicos han devenido discursivamente en patrimonio cultural. La noción de patrimonio es una categoría occidental producida mediante operaciones meta-culturales que extienden valores, significados e interpretaciones del pasado hacia las personas, los grupos y las comunidades; así como a sus conocimientos, prácticas, artefactos, mundos sociales y espacios de vida (KIRSHENBLATT-GIMBLETT, 2004). El patrimonio cultural es considerado como el legado palpable (material o inmaterial) de generaciones pasadas, que apuntala y sedimenta narrativas contemporáneas de identidad (a nivel nacional, regional o local). En este sentido, Rowlands (2002, p. 105) afirma que "[...] vivimos en una era sin precedentes en la preocupación por conservar y restaurar el pasado". Se trata de una agenda que busca definir una especie de conciencia cívica en torno a un supuesto pasado común mediante políticas de identidad cultural, como eje importante de la esfera pública. No obstante, "desde el siglo XVIII en Europa, las colecciones de artefactos culturales y obras de arte han estado asociciadas con la necesidad de conservar 'objetos de valor' para la posteridad, como una crítica hacia la disolución de identidades y relaciones sociales, debido a la emergencia y ascenso del mercado. [Sin embargo] las industrias del patrimonio han sido irónicamente acusadas de mercantilizar 'pasados auténticos' para el turismo, así como para la venta de souvenirs y arte comercial". (ROWLANDS, 2002, p. 106).

${ }^{4}$ Mismo que fue descubierto por Phil Weigand en los años 50's del siglo pasado y comenzó a ser estudiado hacia el año 2006, por parte del arqueólogo Sean M. Smith, investigador de El Colegio de Michoacán.

5 Nombre con el cual se identifica localmente a las personas dedicadas a la búsqueda y recolección de piezas arqueológicas.

${ }^{6}$ Sin embargo, es necesario reconocer que el paradigma monumentalista en la Arqueología nacional ha cambiado y particularmente en el Occidente de México se han desarrollado un conjunto importante de investigaciones de campo en las últimas décadas que han ayudado precisamente a descentralizar y comprender la complejidad de las distintas culturas prehispánicas mesoamericanas.

${ }^{7}$ Louis Pratt (2010) caracteriza este proceso como una "Zona de Contacto" que sirvió al mismo tiempo para establecer narrativas hegemónicas de otredad y para reinventar a Europa. Es decir, la "[...] literatura de viajes escritos por europeos sobre partes no europeas del mundo, crearon el orden imperial para los europeos 'locales', y les otorgaron un lugar dentro de él... los libros de viajes les dieron a los públicos lectores europeos un sentido de propiedad, derecho y familiaridad respecto de las remotas partes del mundo en las que se invertía y que estaban siendo exploradas, invadidas y colonizadas". (2010, p. 24).

${ }^{8}$ El objetivo principal de su investigación fue caracterizar la historicidad del oficio "monero", para comparar precisamente ese tipo de conocimiento cotidiano y local, con el conocimiento científico construído por la arqueología. Algunas de sus preguntas de investigación fueron ¿Qué relaciones sociales se establecieron en lo lícito/ilícito? ¿Existieron alianzas al interior y al expterior (de las instituciones)?¿Cómo se configuran estas redes sociales a través de las cuáles circularon objetos arqueológicos e información?¿Bajo qué circunstancias el campesino se decide a ser monero? Entre otras preguntas orientadas a determinar cuestiones como cuáles eran sus referentes materiales en superficie, cómo eran sus técnicas de excavación, cuáles eran sus conocimientos empíricos del medio ambiente o las formas de tipificar los objetos arqueológicos.

${ }^{9}$ La hipótesis principal de su investigación se podría sintetizar de la siguiente manera: diversos factores, como las demandas internacionales y nacionales de coleccionistas y en general del mercado del arte prehispánico, así como el escaso interés de gobiernos locales, la poco clara política de protección patrimonial, el desconocimiento de las leyes, y el centralismo como agenda ideológica de estado son, entre otros factores, las causas del fenómeno del saqueo de objetos arqueológicos en Nayarit. 
${ }^{10}$ De acuerdo con Özyürek, la omnipresencia del símbolo de Atatürk en el imaginario de la sociedad Turca no es nueva. Lo que es novedoso es la privatización de la producción, circulación y consumo de su imagen, así como las formas y contenidos de sus representaciones (2004). Para plantear su argumento, el autor despliega una metodología que da cuenta de una dimensión histórica -vinculada con los procesos históricos del republicanismo en ese país-; una dimensión política - vinculada con los conflictos ideológicos entre republicanos e islamistas- y finalmente una dimensión simbólica -ligada con las formas de consumo de la ideología estatal por parte de la ciudadanía-. De acuerdo con el autor, a pesar de que el mercado de las esculturas continúa atendiendo necesidades públicas, la década de 1990 presenció la emergencia de un mercado que demandaba diferentes formas de imágenes de Atarturk. De esa manera las mismas compañías privadas que publicaban posters de Pop Stars y anuncios de bebés envueltos en toallas comenzaron a publicar posters de Atartuk en traje de baño o nadando, o bien intervenían viejas fotografías para modificarlas y hacerlas atractivas para el consumo de las nuevas generaciones (2004). Las formas de consumo que identifica el autor van desde una mujer activista de clase media que utiliza un pin con la imagen de Ataturk para mostrar su simpatía con los principios del kemalismo republicano, hasta las imágenes, cuadros y fotografías utilizadas para decorar las oficinas públicas.

11 Aunque cabe señalar que esto no es un fenómeno aislado o exclusivo de la región. En El saqueo del pasado: historia del tráfico internacional ilegal de obras de arte (1973, traducida al español en 1990) Karl E. Meyer elabora un vasto análisis sobre cómo desde mediados del siglo pasado, se han configurado redes internacionales por donde circulan ideas, valores y discursos encarnados en objetos artísticos, históricos y arqueológicos, que son pensados más como mercancía que como patrimonio o como legado identitario. No obstante, rastrear estar redes internacionales desde el ámbito local es una tarea pendiente y será objeto de otro trabajo.

${ }^{12}$ En 1972, junto con la de Ley Federal de Monumentos y Zonas... se creó el Registro Público de Monumentas y Zonas Arqueológicos, Artísticos e Históricos. Es una de las bases de datos, sobre colecciones arqueológicas más grandes del país, toda vez que es un instrumento con el que cuenta el Estado Mexicano (a través del Instituto Nacional de Antropología e Historia INAH) para regular, administrar, conservar y dar fe pública del "patrimono arqueológico de la nación". No obstante, quien se interese por este tipo de información, puede consultar la vasta bibilografía existente sobre legislación y patrimonio en México (COTTOM, 2016).

${ }^{13}$ Voy a omitir en este trabajo los detalles específicos sobre el museo y lo que significó a nivel de patrimonio y la relación con el Estado. En lugar de esto, voy a destacar aspectos específicos sobre los procesos, dinámicas y significados de la práctica de re-colección arqueológica representada por José Guadalupe y dejaré la reflexión sobre el museo para un trabajo posterior.

${ }^{14}$ De acuerdo con investigadores como Isabel Kelly o el mismo Stanley Long, parece existir consenso en la idea de que la región de Ameca-Etzatlán, así como la cuenca de Magdalena (y podríamos decir que gran parte del occidente de México) han sido caracterizados mediante estilos cerámicos y de figuras de arcilla, pero en realidad se conoce poco sobre la cultura que las produjo. A pesar de que algunas investigaciones como las de José Corona Núñez en los años 50’s del siglo pasado permitieron formular ciertas cronologías locales y contextualizar el asentamiento y la procedencia de algunas de estas figuras en las tumbas de tiro, así como situarlas en el tiempo y en el espacio, estos objetos han sido estudiados principalmente mediante sus atributos estéticos y considerándolos como “objetos artísticos". En este sentido y de acuerdo con la tesis de Long, el problema de estudiar piezas arqueológicas como "objetos de arte" radica en la imposibilidad de determinar su significado espacial y temporal. No obstante, el objetivo central Peter Furst y Stanley Long, fue reconstruir el contexto cultural de los grupos sociales que crearon los objetos cerámicos, de concha, obsidiana, etc... integrados en colecciones particulares, así como algunos otros provenientes de excavaciones realizadas previamente por arqueólogos estadounidenses. En este contexto, buscaron sentar bases para desarrollar cronologías y marcos temporales en donde ubicar las piezas a partir de técnicas científicas (seriación y análisis formal de artefactos y figurillas de arcilla, análisis de los 
depósitos de óxido de manganeso, fluorescencia ultravioleta, fechamiento por radiocarbono, análisis de nitrógeno para el material osteológico, etc...) además de situar el contexto territorial y cultural, así como los patrones de enterramiento en algunas de las tumbas de tiro analizadas (El Arenal, Mary Pérez, Santa María, Las cuevas).

${ }^{15}$ Lo cual no es un asunto menor, tomando en cuenta lo que representó la figura de Diego Rivera en el proyecto de construcción nacional, en relación con los vínculos entre arte y poder político que se configuraron en las décadas posteriores a la Revolución Méxicana. Para entender esta discusión, remito al lector al trabajo de Azuela de la Cueva (2005).

${ }^{16}$ Aunque aquí también cabe el planteamiento del patrimonio como un "regalo envenenado" que brinda el Estado como supuesto reconocimiento de las historias vernáculas, siempre que no se salgan del guión de la nación (RUFER, 2016). De manera sintética, el argumento de Rufer gira en torno a la idea de que, en el contexto de las regulaciones sobre patrimonio cultural en México, la figura de los "museos comunitarios" (o locales) reproducen formas de colonialidad interna en la medida en la que solo tienen permitido exhibir su "patrimonio local", siempre y cuando pase por el filtro del Estado y sus agentes de estatalidad. Además de asumir su lugar dentro del espectro más amplio de la nación (en este caso, el museo tuvo que ser validado por las instituciones - INAH, Secretaría de Cultura de Jalisco, Ayuntamiento de Tala, etc...- para poder existir).

${ }^{17}$ Esto tomó una dimensión internacional con las ferias y exposiciones universales europeas de finales del siglo XIX, como dispositivos clasificatorios que reprodujeron una mirada exotizante y colonial sobre los países y sus representaciones. La exposición canalizaba los gustos de las nuevas clases medias y a bajo costo podían comprar los artículos expuestos o bien, adquirir versiones banalizadas de las "obras maestras" de la nación, gracias a su reproducción mecánica. (GONZÁLEZ STEPHAN, 2000).

${ }^{18}$ La estación fue remodelada como parte del proyecto "vías verdes", que busca reactivar las viejas estaciones de la vía construída en el porfiriato, para convertirlas en museos, zonas comunitarias o espacios culturales.

${ }^{19}$ En esta línea, en su libro Collecting Mexico: Museums, Monuments, And The Creation Of National Identity, Shirley Garrigan (2012) desarrolla una reflexión sobre cómo determinadas colecciones, objetos, museos y monumentos, acompañaron el despliegue ideológico del nacionalismo en México.

${ }^{20}$ En este punto, cabe señalar que en la década de 1960 este tipo de figurillas fueron objeto de estudios por parte de arqueólogos norteamericanos. Peter Furst (1966) realizó una crítica la presunción de que las figuras encontradas en las tumbas de tiro eran "seculares y anecdóticas", es decir, que se encontraban libres de simbolismo ritual o de connotaciones sobrenaturales, incluso mágicas. Generalmente, sus contemporáneos utilizaban juicios y criterios de valor occidentales que definían el valor de las piezas a partir de su belleza o la maestría en la elaboración. En este sentido, dicha crítica era en realidad una crítica hacia el concepto de "estética universal" como forma de emparejar criterios artísticos desde la mirada occidental que fue, al mismo tiempo, uno de los criterios más extendidos para valorar la cultura material de las sociedades precolombinas. Específicamente sobre las figuras conceptualizadas como "guerreros" el autor menciona que son muy frecuentes en ofrendas funerarias de tumbas de tiro en Colima, Jalisco y Nayarit, generalmente están acompañados por otros objetos de guerra, por lo que se estableció un canon interpretativo que, sin mucho cuestionamiento, asociaba a las sociedades prehispánicas que originaron dicha tradición funeraria, como sociedades belicosas. En general, su hipótesis es que estas figuras (habitualmente consideradas guerreros), eran en realidad chamanes guardianes de la muerte. 